\title{
Subaerial animal and plant bioerosion in castellated sandstone rocks (Pleistocene to Recent, Czech Republic)
}

\author{
RADEK MIKULÁŠ
}

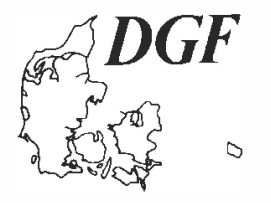

\begin{abstract}
Mikuláš, R.: Subaerial animal and plant bioerosion in castellated sandstone rocks (Pleistocene to Recent, Czech Republic). Bulletin of the Geological Society of Denmark, Vol. 45, pp. 177-178. Copenhagen, 1999-01-30.

https://doi.org/10.37570/bgsd-1998-45-25
\end{abstract}

Rate of bioerosion in some subaerial settings may compete with that of marine bioerosion. Chief agents are plant root activity and microbe metabolism. However, locally, insects may mine sandstone to produce nesting galleries, while tree trunks, moving in storms, may abrade distinctive and long-lasting grooves in the rock. Examples are described from the Quaternary of the Czech Republic.

Key words: Subaerial bioerosion, Czech Republic, bees' nests, plant trace fossils.

R. Mikuláš, Institute of Geology, Academy of Sciences of the Czech Republic, Rozvojová 135, CZ-165 00 Praha 6, Czech Republic. 7 May 1998.

Intensity of bioerosion in some subaerial settings is probably comparable to that of marine lithic substrates. Axial pressure caused by plant roots in rock fissures (Gill \& Brett 1955) and the chemical influence of bac-

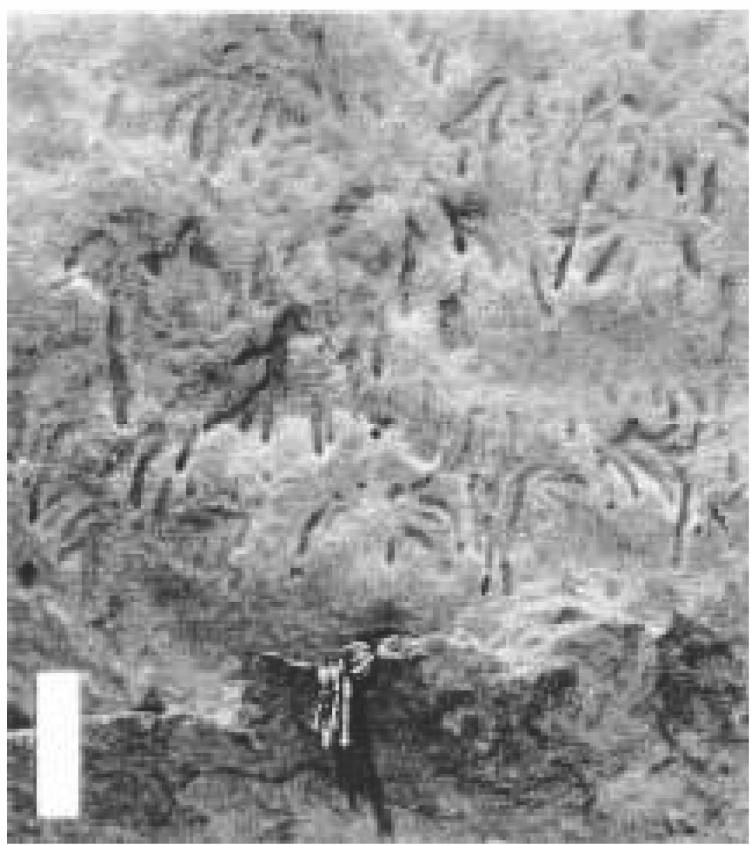

Fig. 1. Recent surface of Late Cretaceous sandstone. Places uncovered by exfoliation of rock crusts show passages interpreted as bees' nests. Sokolka at Turnov, north-eastern Bohemia. Bar scale $=10 \mathrm{~cm}$. teria, green algae and cyanophytes on degradation of rocks (e.g., Silvermann \& Ehrlich 1964) are the most important factors. Subaerial bioerosive structures classifiable as distinctive traces of animal and plant activity are rare and their fossilization potential is very low.

Castellated sandstone rocks situated in the northern part of the Czech Republic are formed of moderately lithified Late Cretaceous sandstones. The imperfect lithification of the substrate contributes to the ease of bioerosion, the effect of which is increased by the action of salt, frost and mechanical erosion. The wellstratified, Late Pleistocene to Recent, mostly non-shifting eolian sediments are jointed, forming sandy talus slopes below overhanging rock surfaces. The sandy substrate contains sandstone cobbles and blocks which show the fossil microrelief (Cílek 1998). These castellated rocks therefore represent an individual case where the products of macroscopical subaerial bioerosion may be fossilized.

Unlined cylindrical tunnels, representing bees' nests, often originated in places where a thin layer of weathered, yet still lithified, sandstone occurred between the hard opalline crust on the rock surface and the rock beneath, which had not been affected strongly by recent weathering processes (Fig. 1). Degraded rock crusts, which may bear parts of these tunnels, also occur on the sandy talus slopes (Mikuláš \& Cílek 1998). Excavation of individual sand grains from the matrix by the strong biting apparatus of mining bees (Fig. 2) is a probable agent of this bioerosion.

Sandstone surfaces that become periodically wet are usually coated with bacteria, algae or lichens, which 


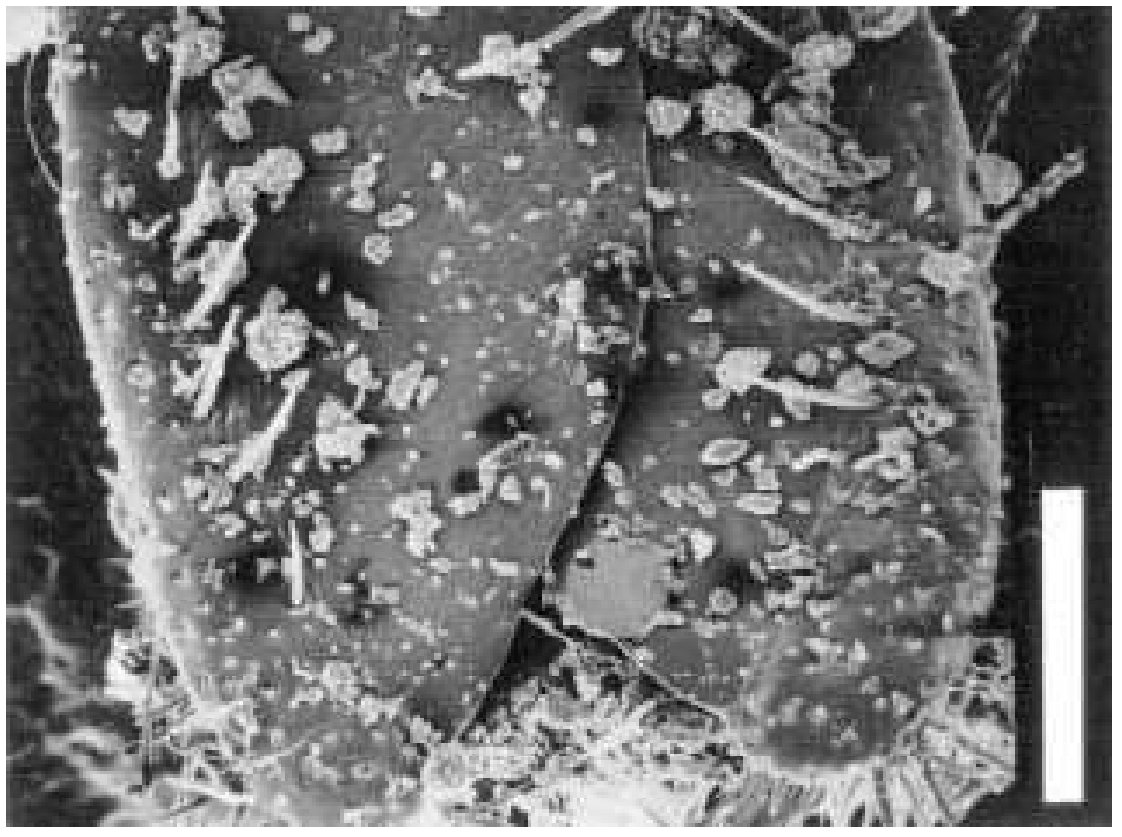

Fig. 2. Biting mouth-parts of a bee species Colletes daviesanus Smith, a tracemaker of some of the breeding tunnels in the castellated sandstones. Northern Bohemia, Stráž pod Ralskem locality. Bar scale $=0.1 \mathrm{~mm}$.

degrade quartz grains and matrix by secreted acids and chelates (Cílek 1998).

Large, vertical, rarely branching grooves, several

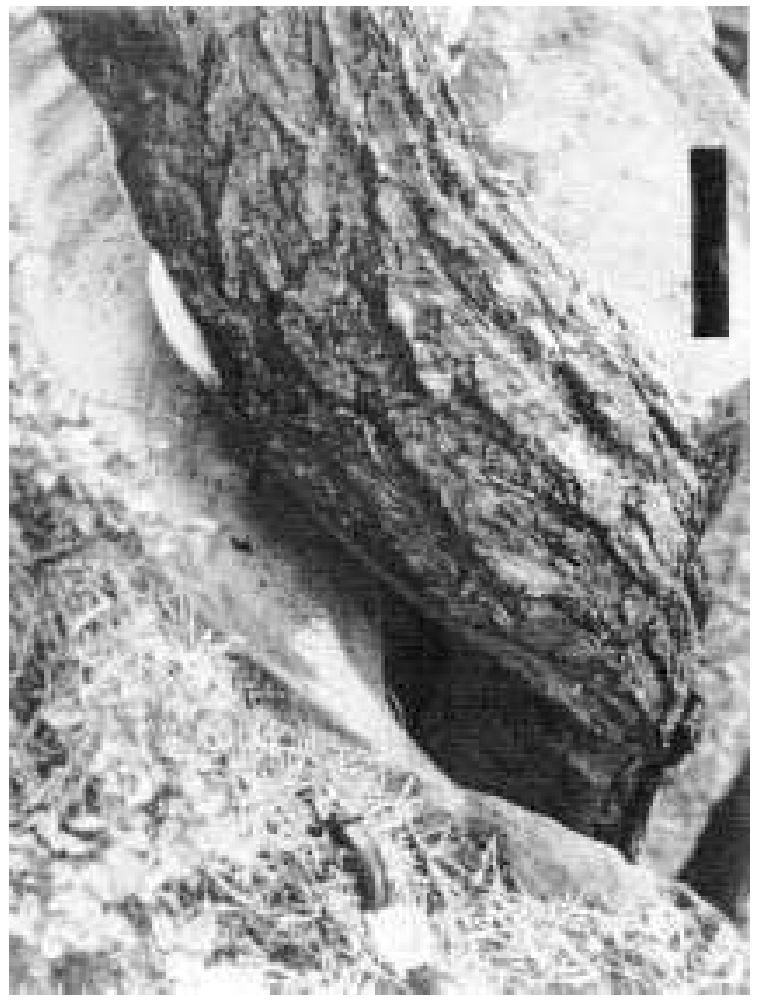

Fig. 3. "Passive bioerosion" - formation of a groove by the stem of a pine tree. Hradčany at Mimoň, northern Bohemia. Bar scale $=10 \mathrm{~cm}$. metres in height and several tens of centimetres in width, originated by long-lasting friction of tree stems on sandstone surfaces (Fig. 3). These "tree troughs" persist in rock surfaces for hundreds or thousands of years.

\section{Dansk sammendrag}

Subærisk bioerosion kan foregå med en hastighed der kan sammenlignes med den i marine miljøer. Hovedagenter er planterødder og mikrobe-stofskifte. Lokalt kan insekter minere sandsten for at danne redegange; medens levende træstammer kan under stormvejr erodere furer i klipper ved deres bevægelser. Eksemplarer er beskrevet fra Tjekkiets kvartær.

\section{References}

Cílek, V. 1998: Fyzikálně chemické procesy vzniku pískovcového pseudokrasu [English summary: The physical and chemical processes of sandstone pseudokarst genesis]. In: Cílek, V. \& Kopecký, J. (eds.) Pískovcový fenomén: klima, život a reliéf, 134-153. Praha: Zlatý Kůň \& Československá speleologická společnost.

Gill, W. R \& Brett, G. H. 1955: Pfeffer's studies of the root growth pressures exerted by plants. Agronomy Journal 47, 166-168.

Mikuláš, R. \& Cílek, V. 1998: Terrestrial insect bioerosion and possibilities of its fossilization (Holocene to Recent, Czech Republic). Ichnos 5, 325-333.

Silvermann, M. P. \& Ehrlich,H. L. 1964: Microbial formation and degradation of minerals. Advances in Microbiology 6, 153-206.

Bulletin of the Geological Society of Denmark 


\title{
Bivalve bioerosion in Oligocene corals from Puerto Rico and Jamaica
}

\author{
DEBRA K. KRUMM
}

Krumm, D. K.: Bivalve bioerosion in Oligocene corals from Puerto Rico and Jamaica. Bulletin of the Geological Society of Denmark, Vol. 45, pp. 179-180. Copenhagen, 1999-01-30.

Twenty-three and 21 species of coral were identified at Puerto Rico and Jamaica localities respectively. Bivalve bioerosion was variably distributed through the species and on average only $8.5 \%$ coral substrate was removed. Bivalves play little role in toppling or breakage of coral colonies.

Key words: Bioerosion, Oligocene, Puerto Rico, Jamaica, Lithophaga, patch reef.

D. K. Krumm, Harbor Branch Oceanographic Museum, 5600 U.S. 1 North, Fort Pierce, Florida 34946, USA; 16 July 1998.

Distribution, abundance, and diversity of bioeroding bivalves and their host corals were analyzed from the Oligocene Lares Formation near Lares in northwest- ern Puerto Rico and Brownstown Formation south of Brownstown in north-central Jamaica (Krumm 1993, 1994, 1996). Fossils were mapped and collected from

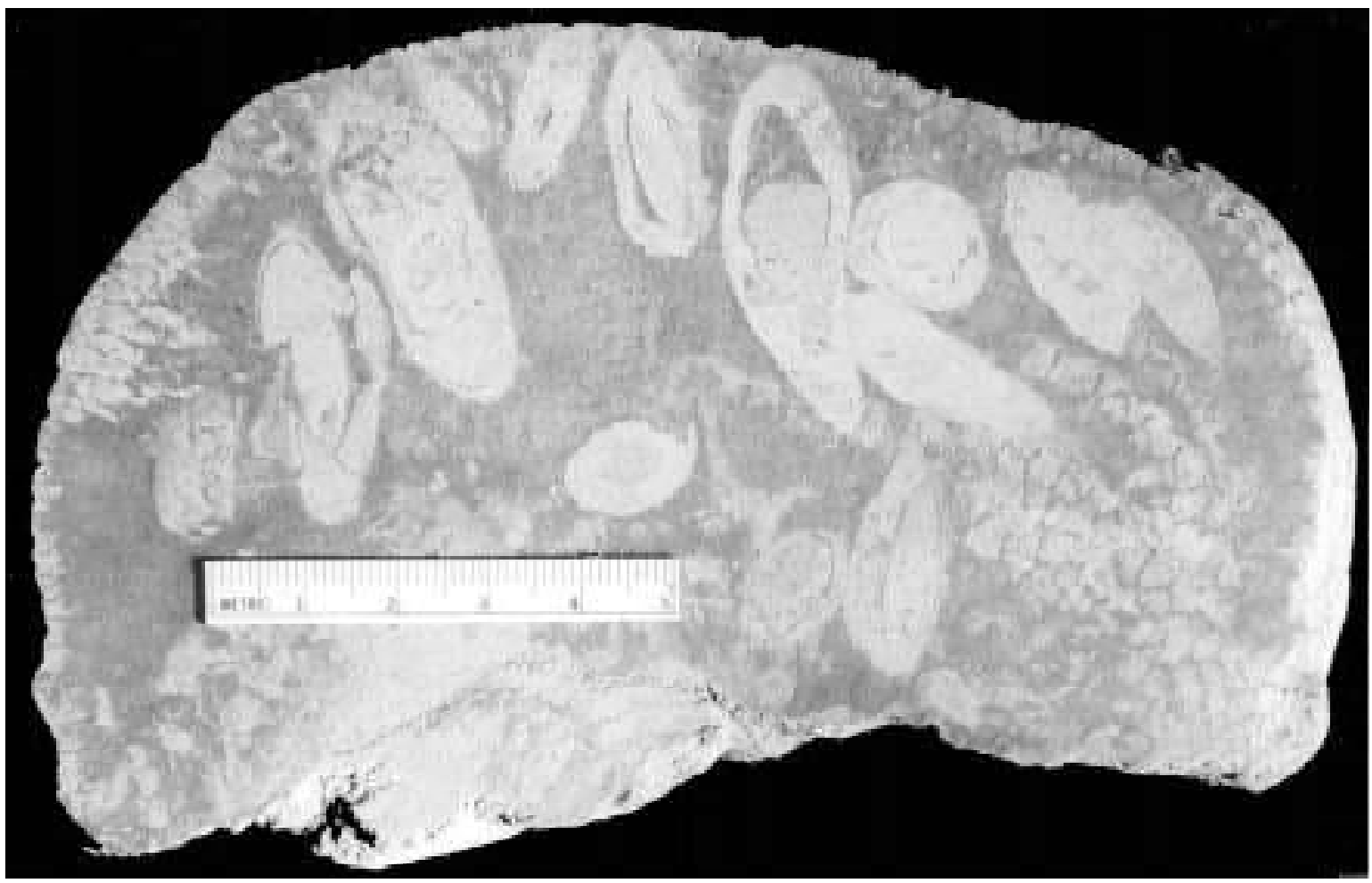

Fig. 1. Cross-section through Goniastrea canalis (University of Colorado Museum \#32192) illustrating several generations of borers, shells in boreholes, backfilled boreholes, and geopetal fill. Borers are located primarily in the upper portion of coral skeleton. Twenty-seven percent of the skeleton has been removed. Centimeter scale. 
laterally-continuous square-meter grids located on vertical cross-sections through patch reefs. Twentythree coral species were identified from Puerto Rico. The Jamaican grids yielded 21 coral species.

Large variations in amounts of bioerosion exist between coral genera. Three coral genera from Lares (Colpophyllia, Diploastrea, and Astreopora) are lightly bored by bivalves, while heavy bioerosion of Montastraea, Porites, and Goniastrea occurs in both Lares and Brownstown formations. Back-filled boreholes indicate that some bivalves inhabited living coral (Figure 1). Four lithophagid bivalve species, two gastrochaenid bivalve species, and one species of Petricola have been identified. Of 58 corals sectioned from the Lares Formation, 43 contain bioeroding bivalves. The average amount of coral skeleton removed by bivalves is $8.5 \%$, with a $1 \%$ to $40 \%$ range.

Distribution data reveal that bivalve boring was neither the primary cause of branching coral breakage nor of massive coral toppling from undercutting. Only $13 \%$ of exposed surfaces of the branching coral, Acropora saludensis, and $11 \%$ of branching Porites portoricensis specimens from Lares contain any bivalves. The upper four-fifths of massive coral skeletons contain $80 \%$ of the bivalve borers (Figure 1).

In conclusion, amount of damage to corals by bioeroding bivalves varied between environments and between coral species. Damage was less than predicted with an average of $91.5 \%$ of the coral skeleton left intact and a relatively even dispersal of bioeroding bivalves throughout the massive corals. It is proposed that diversity and abundance of corals and borers were primarily controlled by fluctuations in sea level and nutrient levels (Krumm 1996).

\section{Dansk sammendrag}

Henholdsvis 23 og 21 arter koraller blev identificeret fra forskellige lokaliteter i Puerto Rico og på Jamaica. Bioerosion ved boremuslinger havde variabel udbredelse blandt koralarterne og i gennemsnit var kun $8,5 \%$ koralunderlag fjernet af muslinge bioerosion. Muslinger spiller en forholdsvis lille rolle i kipning og brud af koralkolonier.

\section{References}

Krumm, D. K. 1994: Abundance and diversity of bivalve borers as indicators of environmental stress on host corals. Geological Society of America Abstracts with Programs 26, 374.

Krumm, D. K. 1996: Endolithic Bivalves and Host Corals from the Upper Oligocene Lares Formation of Puerto Rico. Unpublished PhD dissertation. University of Colorado, Boulder, $322 \mathrm{pp}$

Krumm, D. K. \& Santos, H. 1993: Comparison of cross- sections from Cretaceous, Paleocene, and Oligocene 'reefs' in the Caribbean and SE-United States. Geological Society of America Abstracts with Programs 25, 58. 